\title{
PRODUCTIVE AND PHYSIOLOGICAL EFFECTS OF CHAMOMILE AND ROSEMARY AQUEOUS EXTRACT ON NEW ZEALAND WHITE GROWING RABBITS.
}

\author{
Z.A.A. Mousa ${ }^{1}$, H.A. Daghash ${ }^{2}$, A.A. Azoz ${ }^{1}$, M.S.M. Mousa ${ }^{2}$ and M.M. \\ Farghaly $^{2}$ \\ ${ }^{1}$ Animal Production Research Institute, Agriculture Research Center, Ministry of \\ Agriculture, Egypt. \\ ${ }^{2}$ Deptment of Animal Production, Faculty of Agriculture, Assiut University, \\ Egypt. \\ e-mail:zeinabmousa@yahoo.com
}

\section{ABSTRACT:}

This study was conducted to evaluate the effects of some herbal extracts on growth performance and blood parameters of growing New Zealand White (NZW) rabbits under Upper Egypt conditions of the summer season. Seventy two weaned rabbits At 5 week's age $(743.17 \pm 12.4 \mathrm{~g}$ body weight) were randomly divided into 6 groups. Control group, rabbits received water without additives. In $C 1$ and $C 2$ groups, rabbits received chamomile aqueous extract at 5 and $10 \mathrm{ml} / \mathrm{L}$ of drinking water, respectively. In $R 1$ and $R 2$ groups, rabbits received rosemary aqueous extract at 5 and $10 \mathrm{ml} / \mathrm{L}$ of drinking water, respectively. The last group (CR) rabbits received a mixture from chamomile and rosemary aqueous extract $5 / L$ water. During the experimental period the body weight, average daily gain, feed intake (FI), feed conversion ratio (FC) and some blood parameters were estimated. Also, the mortality rate was calculated.

The result revealed that the supplement a combination of chamomile and rosemary $(C R)$ increased $(P<0.05)$ average body weight gain and daily gain as compared $C 1, R 1$ and $R 2$ groups. The feed intakes did not affected between the treated groups and control one. However, the feed conversion ratio was significant improved $(P<0.01)$ of rabbits drinking water contains a mixture of chamomile and rosemary extracts $(C R)$ when compared with rosemary groups (Rland $R 2$ ). The Serum total protein (TP), albumin, glucose, total cholesterol and triglyceride concentrations were significantly lower $(P<0.05)$ in all treated groups than control group. Supplementing chamomile at levels $5 \mathrm{ml}$ and $10 \mathrm{ml} / \mathrm{L}$ to drink water of rabbits decreased the concentration of serum urea and creatinine when compared with control group. Supplement rosemary extract at $10 \mathrm{ml} / \mathrm{L}$ to drinking water of growing rabbits increased $(P<0.05)$ the number of WBCs as compared with control group (7.07 vs. $3.65 \times 10^{3}$, respectively). 
The percentages of white blood cell differential (lymphocytes, neutrophils, monocytes and eosinophil) were not significantly affected by treatment. The RBCs count was decreased $(P<0.05)$ with supplement chamomile aqueous extract $(10 \mathrm{ml} / \mathrm{L})$ to drinking water as compared with control one (4.09 vs. $4.87 \times 10^{6} / \mu l$, respectively). The supplement rosemary aqueous extract alone in $R 2$ group or their combination with chamomile extract in the $C R$ group improved $(P<0.05)$ hemoglobin $(H G B)$ and hematocrit (HCT) concentration in compassion to control group and other treated groups.

In conclusion, supplement herbals plants extract particularly chamomile aqueous extract or it is mixture with rosemary to drink water of growing rabbits has a positive effect on blood parameters and improves growth performance under heat stress condition.

Key words: Productive \& physiological effects, chamomile, rosemary aqueous extract, rabbits.

\section{INTRODUCTION}

Many efforts have been devoted to use the green natural materials and/or medicinal plants as feed additives to improve the efficiency of feed utilization and productive performance of animals and these efforts are widely accepted. The use of chemical products especially (hormones and antibiotics), may cause unfavorable side effects. Moreover, there is evidence indicating that these products are currently considered risky pollutants for human and may threaten their health on the long-run (Omer et al., 2013).

Recently, there is a great interest in using phytogenic as a conceivable option to enhance a variety of critical processes in food animal physiology without adverse effects on human health and environment. Also, it has been reported that the use of herbs, spices, and various plant extracts because of its appetizing, digestion-stimulating and antimicrobial properties (Zhang et al., 2018). The use of a wide range of phytogenic feed additives in rabbit nutrition has recently become a common management practice, since plant based feed additives have demonstrated to enhance rabbit growth performance, improve animal oxidative status. Prevent and treat certain pathological conditions and acting as rabbit product quality enhancers (Assan, 2018). There are a large number of feed additives available for inclusion in the rabbit's diets to improve their performance (Ewuola et al., 2011).

Many scientific literature have revealed that rosemary plant is rich in many bioactive compounds, foremost, phenolic diterpenes, which a variety of healthpromoting properties, such as antimicrobial, anti-infectious, antioxidant, particularly carnosic acid, carnosol or rosmanol; triterpenes e.g ursolic acid; 
flavonoids e.g genkwanin, cirsimaritin (Zeghad and Merghem 2016 and Fiume et al., 2018).

Recent research supports using chamomile due to the phenolic content (specifically flavonoids) which possess anti-oxidant power and antitumor agents, due to polyunsaturated fatty acids (PUFAs) are sensitive to oxygen-induced damage mediated by lipid peroxidation, and thus are sensitive to reactive oxygen species attacks, so an excessive production of reactive oxygen species, exceeding the all antioxidant capacity, leads to the oxidative stress, which is harmful to growth performance (Sotiropoulou et al., 2020 and Matić et al., 2013).

Therefore, the present study investigates the productive and physiological effect of chamomile and rosemary aqueous extract on New Zeland growing rabbits.

\section{MATERIALS AND METHODS}

\section{Preparing Rosemary and Chamomile Extraction}

Rosemary (Rosmarinus officinalis L.) and Chamomile (Matricaria chamomile L.) plants were collected from a private commercial farm located in New Valley governorate. The leaves were harvested, air-dried under shade until the moisture of collected leaves reached $10 \%$. The dry leaves were finally milled, sieved (1 mm mesh) and stored in a well tight polyethylene bags at room temperature of $25^{\circ} \mathrm{C}$.

One hundred grams of dried leaves of Rosemary and fifty grams of Chamomile were taken and soaked in one liter of boiling distilled water in a covered flask, then shaken and stirred for 6 hours at room temperature. Once the flask content had cooled off to $25^{\circ} \mathrm{C}$, the solution was filtered with a syringe filter to remove the leaves and debris (Double Rings filter paper 102, $11.0 \mathrm{~cm}$ ) (Emam, 2012). Rabbits were given an aqueous extract of Rosemary and Chamomile daily in drinking water of rabbits for 7 wks.

\section{Active compounds analysis of the extracts}

The flavonoids and Phenolics compounds of chamomile and rosemary aqueous extracts were analyzed using methodology of HPLC chromatography and are presented in Table 1.

\section{Flavonoids}

Analyses were performed by HPLC-(Agilent 1100) is composed of a two LC- pumps pump, a UV/Vis detector. C18 column $(250 \times 4.6 \mathrm{~mm}, 5 \mu \mathrm{m})$. The mobile phase was acetonitrile (A) and $0.2 \%(\mathrm{v} / \mathrm{v})$ aqueous formic acid (B) with a Isocratic elution (70: 30) program The detection wavelength was set at $360 \mathrm{~nm}$ (Mizzi et al., 2020). 
Table(1): HPLC analysis of flavonoids and phenolics compounds of rosemary and chamomile extracts.

\begin{tabular}{|c|c|c|c|c|c|}
\hline \multirow[b]{2}{*}{ Items } & \multicolumn{2}{|c|}{ Flavonoids } & \multirow[b]{2}{*}{ Items } & \multicolumn{2}{|c|}{ Phenolics } \\
\hline & $\begin{array}{c}\text { Chamo } \\
\text { mile } \\
(\mu \mathrm{g} / \mathrm{ml})\end{array}$ & $\begin{array}{c}\text { Rosemary } \\
(\mu \mathrm{g} / \mathrm{ml})\end{array}$ & & $\begin{array}{l}\text { Chamomi } \\
\text { le }(\mu \mathrm{g} / \mathrm{ml})\end{array}$ & $\begin{array}{c}\text { Rosemary } \\
(\mu \mathrm{g} / \mathrm{ml})\end{array}$ \\
\hline Catechin & 6.52 & 7.88 & Caffeic & 3.14 & 20.63 \\
\hline Hisperdin & 11.56 & 3.01 & Catechol & 8.24 & 7.18 \\
\hline Kampferol & 3.17 & 2.06 & Ellagic & 6.23 & 22.14 \\
\hline Luteolin & 2.88 & 6.14 & Ferulic & 4.14 & 19.33 \\
\hline Naringin & 5.33 & - & p-coumaric & 11.52 & 8.22 \\
\hline Querestin & 11.04 & 12.65 & Protocatechulic & 19.13 & 8.2 \\
\hline Rutin & 4.57 & 4.06 & Pyrogallol & - & 16.51 \\
\hline Rosamirinic acid & - & 10.33 & Syringic & 14.5 & 9.66 \\
\hline 7-OH flavone & - & 7.25 & ------ & -- & -- \\
\hline
\end{tabular}

\section{Phenolics}

Analyses were performed by HPLC-(Agilent 1100) is composed of a two LC - pumps pump, a UV/Vis detector. C18 column $(125 \times 4.60 \mathrm{~mm}, 5 \mu \mathrm{m}$ particle size). Chromatograms were obtained and analyzed using the Agilent Chem Station Phenolic acids was separated by employing a gradient mobile phase of two solvents was used- Solvent A (Methanol) and Solvent B (Acetic acid in water (1:25). The gradient program was begun with $100 \% \mathrm{~B}$ and was held at this concentration for the first 3 minutes. This was followed by $50 \%$ eluent $\mathrm{A}$ for the next 5 minutes after which concentration of $\mathrm{A}$ was increased to $80 \%$ for the next 2 minutes and then reduced to $50 \%$ again for the following 5 minutes detection wave length at $250 \mathrm{~nm}$ (Mizzi et al., 2020).

\section{Animals, management and diets}

A total number of 72 weanlings New Zealand White growing rabbits 5 weeks of age with an average initial body weight $743.17 \pm 12.4 \mathrm{~g}$ were obtained from a local commercial farm. Rabbits were randomly distributed into 6 treatments each containing 12 rabbits in three replicates of five rabbits each $(6$ treatment $x 3$ replicates $x 4$ rabbit $=72$ ) with nearly similar means of weaning body weight. Rabbits were kept in an open system house in cleaned cages of wire floor batteries the dimensions of the cage was $(45 \times 45 \times 38 \mathrm{~cm})$ for length, width, and height, respectively. Conventional management procedures were used throughout the experimental period. Deworming of rabbits was carried out before the beginning of the experiment. Rabbits were vaccinated for Bacterial hemorrhagic disease at 1 months of age. Manure was dropped from the cages on the floor and were collected and removed daily. The chemical composition of the 
basal diet is crude protein (18\%), ether extract (2.80\%) and crude fiber (13.60\%), ME $(2800 \mathrm{kcal} / \mathrm{kg}$ diet). The commercial pelleted diet and water were offered ad-libitum under a total of 12 hours light/day during the experimental periods (5-12 weeks of age). The air temperature, relative humidity and temperaturehumidity index inside the building during the time of experiment were measured daily. The air temperature was ranged between 26 and $35^{\circ} \mathrm{c}$, relative humidity was ranged between 19 and 48 and temperature humidity index (THI) was ranged between 70 and 84 , which calculating by using the following equation: $\mathrm{THI}=(1.8 \times \mathrm{T}+32)-(0.55-0.0055 \times \mathrm{RH}) \times(1.8 \times \mathrm{T}-26)$

Where $\mathrm{T}$ is the air temperature $\left({ }^{\circ} \mathrm{c}\right)$ and $\mathrm{RH}$ the relative humidity $(\%)$ according to Tucker, et al., (2008).

The experimental design of six treatments of NZW growing rabbits as follows: 1- Control: Rabbits received daily water without any additives.

2- C1: Rabbits received daily chamomile aqueous extract at $5 \mathrm{ml} / \mathrm{L}$ drink water.

3- C2: Rabbits received daily chamomile aqueous extract at $10 \mathrm{ml} / \mathrm{L}$ drink water.

4- R1 Rabbits received daily rosemary aqueous extract at $5 \mathrm{ml} / \mathrm{L}$ drink water.

5- R2: Rabbits received daily rosemary aqueous extract at $10 \mathrm{ml} / \mathrm{L}$ drink water.

6- CR: Rabbits received a mixture from chamomile and rosemary aqueous extract at $5 \mathrm{ml} / \mathrm{L}$ drink water.

\section{Growth performance parameters}

The average body weight gain and average daily gain of rabbits was measured every week before morning feeding. The Average feed intake of each replicate was recorded weekly per animal. Feed conversion ratio was calculated and expressed in terms of gm. dry matter (DM) intake per gm. body weight gain. The mortality rates were measured every week during the experiment period.

\section{Blood constituents}

At the end of the experiment about $7 \mathrm{ml}$ of blood samples were collected from six rabbits per group during the bleeding stage of the slaughter process and blood samples were collected in a sterile centrifuge tubes. Each blood sample was divided into three parts. The first part was placed in tubes containing ethylene diamante tetra acetic acid (EDTA) for hematology. The second part was put in tube for separation the serum for determines the biochemical parameters. The last part was placed in tubes containing heparin for the immunological estimation. The samples were directly centrifuged at $3000 \mathrm{rpm}$ for $15 \mathrm{~min}$ and the serum was recovered and stored at $-20{ }^{\circ} \mathrm{C}$ in eppendorf tubes until analysis. However, the samples that use in immunity measurements the serum was stored at $-80{ }^{\circ} \mathrm{C}$ in eppendorf tubes until analysis. All of the blood samples that use hematology and serum biochemistry were performed using standard protocols. 


\section{Haematological parameters}

The hematological parameters were assessed by using automatic, fully Digital Hematology Analyzer (Shenzhen Mind ray Auto Haematology Analyser (Model Bc-3200, Shenzhen Mind ray Biomedical Electronics Co. Hamburg 20,537, Germany). These parameters included a total count of white blood cells (WBC's), and its differential percent of each cell (Eosinophil\%, Lymphocytes\%, Neutrophils \%, Blastocyst \%). Also the total count of red blood cells (RBC's), hemoglobin ( $\mathrm{g} / \mathrm{dl}, \mathrm{HGB}$ ), hematocrit (HCT, packed cell volume, PCV,\%), platelets (PLT, \#10 ${ }^{3} \mathrm{~mm} 3$ ), mean corpuscular hemoglobin $(\mathrm{MCH}, \mathrm{pg})$, mean corpuscular volume $(\mathrm{MCV}, \mu \mathrm{m} 3)$, mean corpuscular hemoglobin concentration (MCHC , g/dl), and mean platelet volume(MPV, $\mu \mathrm{m} 3)$ were determined.

\section{Blood components}

Plasma samples were analyzed for plasma total protein, albumin, urea, creatinine, triglycerides and total cholesterol were determined by colorimetric method using kits produced by Spectrum-diagnostics.com, MDSS GmbH, Schiffgraban 41, 30175 Hannover, Germany. While the plasma globulin concentration was determined by subtract the total protein from albumin. Total antioxidant capacity, Nitric oxide and Hydrogen peroxide $\left(\mathrm{H}_{2} \mathrm{O}_{2}\right)$ were assayed using commercial kits supplied by Biodiaggnostic Assay Kits (WWW.biodiagnostic.com, Giza, Egypt).

\section{Statistical analysis:}

Statistical analysis was carried out using a general linear model (G.L.M) of SAS (2001) program. Effect of treatments on feed intake, growth rate, feed conversion ratio, blood parameters were evaluated by one-way ANOVA. The statistical analysis using the following model:

$$
\mathbf{Y}_{\mathrm{i}}=\boldsymbol{\mu}+\mathbf{T}_{\mathrm{i}}+\mathbf{e}_{\mathrm{ij}}
$$

Where $Y_{i j}$ is any observation by treatments $T_{i}$ for $i=(1-6)$ types, $\boldsymbol{\mu}=$ The population mean, $\mathbf{T}_{\mathbf{i}}=$ Treatments effect ( $\mathrm{i}=$ Control, C1, C2, R1, R2 and CR), $\mathbf{e}_{\mathrm{ij}}=$ Experimental error.

The significant differences between treatment means were tested by Duncan Multiple Range Test (Steel and Torrie, 1980). The data are presented as means \pm SE. Probability values of less than $0.05(\mathrm{P}<0.05)$ were considered to be significant.

\section{RESULTS AND DISCUSSIONS}

\section{Growth performance}

Results presented in Table (2) shown that supplement combination of chamomile and rosemary (CR) aqueous extract $(5 \mathrm{ml} / \mathrm{L})$ to drinking water of 
EFFECTS OF CHAMOMILE \& ROSEMARY AQUEOUS EXTRACT ONRABBITS . 223

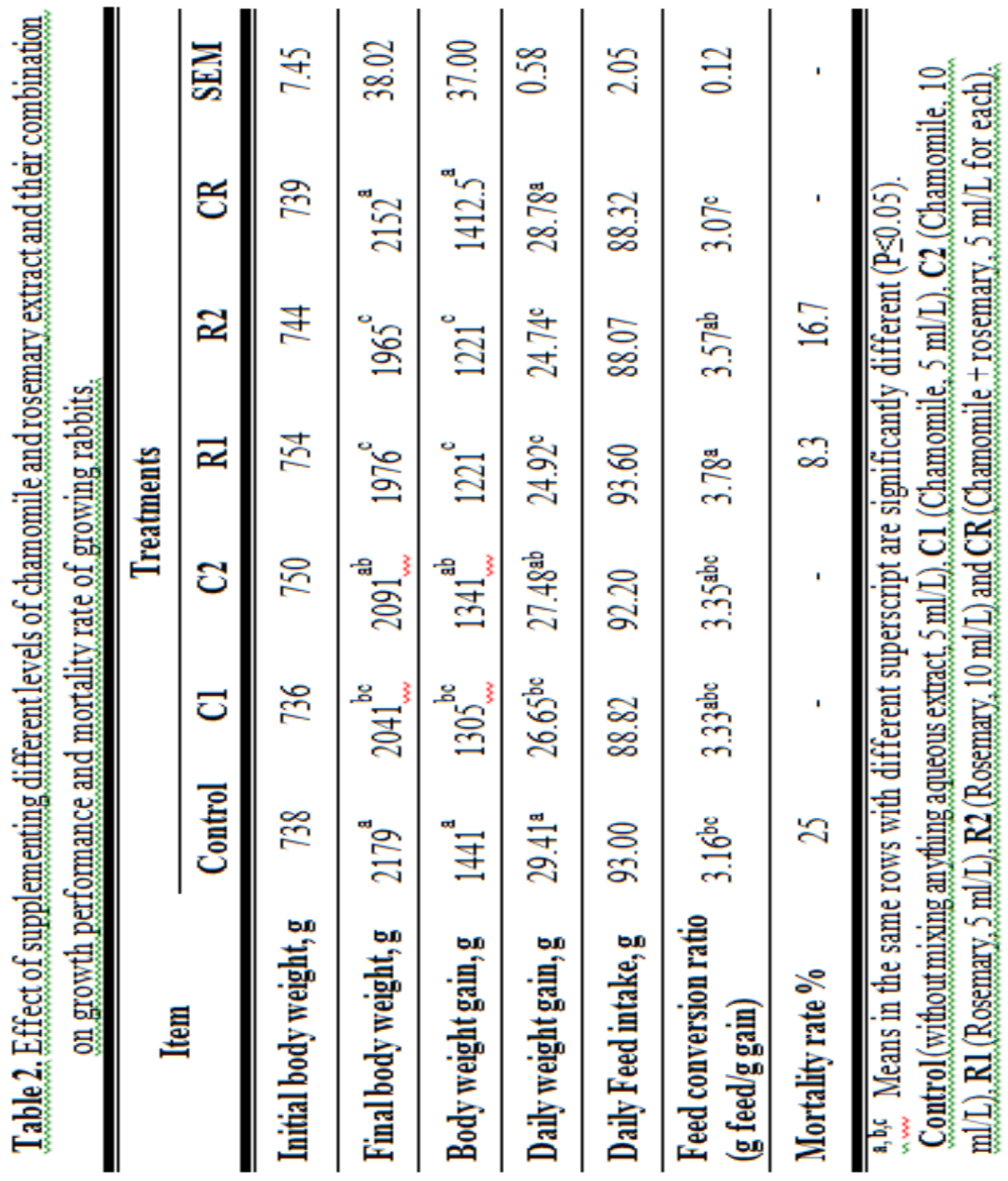


growing rabbits increased $(\mathrm{P}<0.05)$ average body weight gain and daily gain as compared C1, R1 and R2 groups. However, no significant differences were found among CR, C2 and control groups. On the other hand, the final body weight and body weight gain of rabbits consumed water contains extract of rosemary at rate $5 \mathrm{ml}(\mathrm{R} 1)$ and $10 \mathrm{ml} / \mathrm{L}(\mathrm{R} 2)$ were lower $(\mathrm{P}<0.05)$ than those in control and other treatments groups. These results may be related to aggravation of digestive disorders with supplement rosemary aqueous extract to drinking water that caused a reduction in final BW and BWG. Harach et al. (2010) showed that mice treated with $20 \mathrm{mg} / \mathrm{kg} \mathrm{BW}$ of rosemary extract (RE) tended to have a lower body weight after 35 days of treatment. Also, the final weight gain of mice treated with $200 \mathrm{mg} / \mathrm{kg}$ BW of rosemary extract (RE) was significantly reduced by $64 \%$ when compared with the control group. The same author attributed the reduction in body weight gain with treated mice by rosemary extract to inhibit pancreatic lipase activity and a limitation of lipid absorption. The reduction of weight gain was stronger in mice treated with rosemary extract (92\% as compared with the control group) than in mice treated with pure carnosic acid (7\% as compared with the control group) (Ninomiya et al., 2004).

Data presented in Table (2) shown that no significant effect on feed intake between the treated groups and control one. However, the feed conversion ratio (FCR) was significant improved $(\mathrm{P}<0.01)$ of rabbits drinking water contains a mixture of chamomile and rosemary extracts (CR) when compared with rosemary groups (R1and R2) which was (3.07 vs. 3.78 and $3.57 \mathrm{~g}$ feed/ g gain, respectively).While, no significant differences in feed conversion ratio (FCR) were detected between the chamomile and rosemary groups (Table 2). These results agreement with this reported by El-Wardany et al. (2015) and Helal et al. (2017). Abaza et al. (2014) attributed the improve FCR with rabbits fed a diet containing $0.25 \%$ chamomile flowers due to increasing volatile fatty acids production and organic matter digestibility, in addition, Erdelyi et al. (2008) reported that supplemented rabbits with rosemary or combination of garlic and rosemary essential oils had no influence on growth rate, but increase an aggravation of digestive disorders causing diarrhea and reduction on FCR.

The results of this study revealed that the inclusion of chamomile in drinking water of $\mathrm{C} 1$ and $\mathrm{C} 2$ groups or it is combination with rosemary in CR group decreased the mortality rate to zero \% when compared with the control and rosemary groups (Table 2 ). The mortality rate increased with rabbits received 5 $\mathrm{ml}$ and $10 \mathrm{ml} / \mathrm{L}$ of rosemary extracts by about 8.3 and $16.7 \%$, respectively. Also, the mortality rate was $25 \%$ in control group. The positive effect of chamomile extracts on reducing mortality rate of growing rabbits in this study seems to be in agreement with the previous results reported by Rassolov and Voroshilin (2018) stated that chamomile has antibacterial, inflammation and pain, protects the 
gastric mucosa from irritants, absorbs toxic substances, and cleanses the body. However, Badawi et al. (2016) found that increasing the level of rosemary from 1.5 to $3 \%$ of the diets of rabbits increased $(\mathrm{P}<0.05)$ the mortality rate compared to control group.

\section{Blood constituents}

The data of the blood constituents are summarized in Table 3. Results indicated that the average values of total protein (TP) and albumin in blood serum of rabbits received different levels of chamomile (C1-C2) and rosemary (R1) extracts or their combination $(\mathrm{CR})$ were significantly $(\mathrm{P}<0.05)$ lower than control group. However, rabbits received $10 \mathrm{ml} / \mathrm{L}$ rosemary (R2) extracts was higher $(\mathrm{P}<0.05)$ of total protein and albumin than other treatments groups. While, no significant differences were observed among treatment groups and control group for globulin. The values of serum total protein, albumin and globulin in all different groups were within the normal range as reported in the literature (Osman et al., 2021).

The data in Table (3) revealed that the serum glucose was significantly decreased $(\mathrm{P}<0.05)$ of all treatments groups in comparison with control group. The rabbits in $\mathrm{C} 2$ group recorded the lowest value of glucose concentration followed $\mathrm{C} 1$ then $\mathrm{R} 1$. The glucose concentration was higher in the rabbits drinking water with $10 \mathrm{ml} / \mathrm{L}$ rosemary extract (R2) or a blend of extract rosemary and chamomile (CR) than in the other treatments. The decreases of blood serum glucose level with supplementing chamomile extract may be due to pharmacological activity of Chamomile on insulin secretion (Eddouks et al., 2005). Similarly, Cemek et al. (2008) stated that the administration of chamomile extract showed an antihyperglycemic effect, which controls the blood glucose level through a protective effect on pancreatic beta cells which leads to diminishing hyperglycemia-related oxidative stress. In addition, Al-Jamal and Algadi (2011) reviewed that rosemary has anti-diabetic properties in terms of improving glucose utilization and oxidative metabolism of diabetic states in rats. The results of our study agreement with those reported by Hamden et al. (2008) and Bakr et al. (2017) they indicated that rabbits received chamomile and rosemary were significantly reduced serum glucose when compared to control group.

The serum total cholesterol and triglyceride concentrations were significantly lower $(\mathrm{P}<0.05)$ in all treated groups than control one (Table 3$)$. The total cholesterol concentration was increased $(\mathrm{P}<0.05)$ in serum of rabbits received $10 \mathrm{ml} / \mathrm{L}$ rosemary extract $(\mathrm{R} 2)$ in comparison with rabbits received chamomile extract $5 \mathrm{ml} / \mathrm{L}(\mathrm{C} 1)$. Also, the triglyceride concentration was higher in R1 than CR. However, no significant differences were detected among other treatment groups. The change in lipid profile in the groups received chamomile 
MOUSA et al.

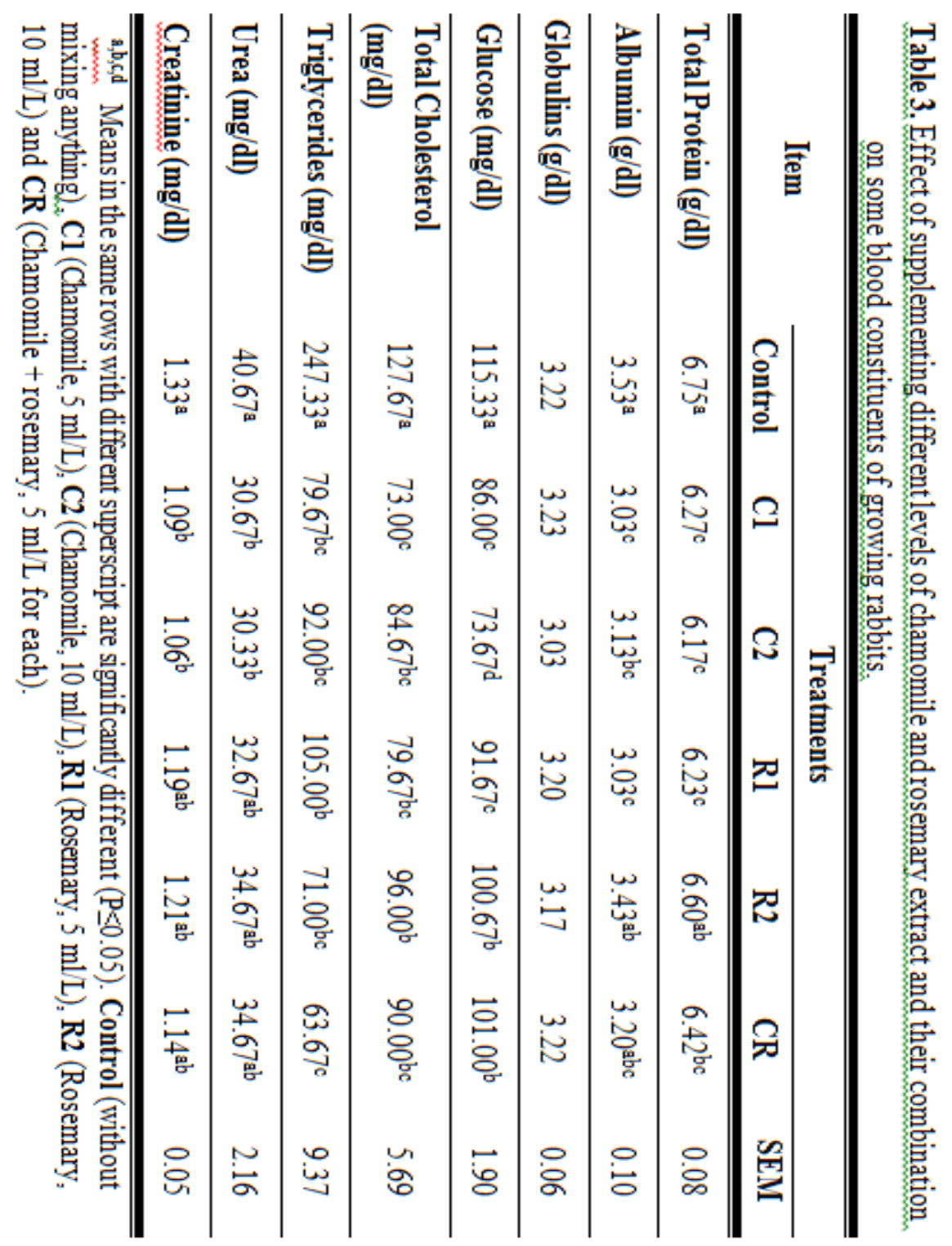


may be attributed to hypolipidemic effect of chamomile flowers extract contains a high contentment of flavonoids $(63.3 \%)$ most of them are apigenin and total phenolic compounds $(23.2 \%)$, bioactive compounds announced acting as a oxidative factors scavenger (Gupta and Misra 2006 and Avallone et al., 2000). Similarly, Rafraf et al. (2015) reported that chamomilla extract as a natural material, decreasing of blood cholesterol by two pathways by the presence of flavonoids that enhance the phosphorylation of Hydroxy-methylglutaryl-CoA (HMG CoA) reductase enzyme indirectly thus diminish endogenous cholesterol production, Also, Iweala and Oludare, (2011) concluded that rosemary had a hypolipidemic effect due to the antioxidant effect of its constituents, which changed the rate of fatty acids oxidation in the liver and reduced the rate of triglycerides biosynthesis and reduced the rate of triglycerides biosynthesis in rats. Similar results of reduction in cholesterol and triglyceride concentrations due to chamomile and rosemary supplementation were reported by Gupta and Misra (2006); Nargesi et al. (2018) and Gabr (2016).

The results in Table (3) showed that supplementing chamomile at levels $5 \mathrm{ml}$ and $10 \mathrm{ml} / \mathrm{L}$ to drink water of rabbits decreased the concentration of serum urea and creatinine when compared with control group. However, no significant differences were found among treatments or between other treated groups and control. The values of Urea and creatinine concentration of rabbits in our study were within the normal range (20-45 and $0.5-2.5 \mathrm{mg} / \mathrm{dl}$, respectively) according to Melillo (2007). The consumption of chamomile as antioxidants is one of the most important treatment strategies to cause a reduction in serum urea and creatinine in patients (Kaseb et al., 2018). Similarly, Sampaio et al. (2016) reported that the decrease in serum level of urea and creatinine in animals treated with chamomile might be due to the antioxidant action of chamomile. Also, Shati and El-kott (2014) reported that treatment with chamomile caused insignificant changes in the blood urea and creatinine in induced hepato- nephrotoxicity of rats.

\section{Hematological of white and red blood cells}

As shown in Table (4) supplement rosemary aqueous extract at $10 \mathrm{ml} / \mathrm{L}$ to drinking water of growing rabbits increased $(\mathrm{P}<0.05)$ the number of WBCs as compared with control group (7.07 vs. $3.65 \times 10^{3}$, respectively). However, no significant differences were detected among treated groups. Also, the percentages of white blood cell differential (lymphocytes, neutrophils, monocytes and eosinophil) were not significantly affected by treatment. The percentage of neutrophils was numerical lower in C2 and R2 than other groups. Meanwhile, the percentages of monocytes tended to be higher in all treated groups except R1 which was similar to control value. The total number of WBCs and cell profile of all groups were in the normal physiological ranges (5.5-12.5 
MOUSA et al.

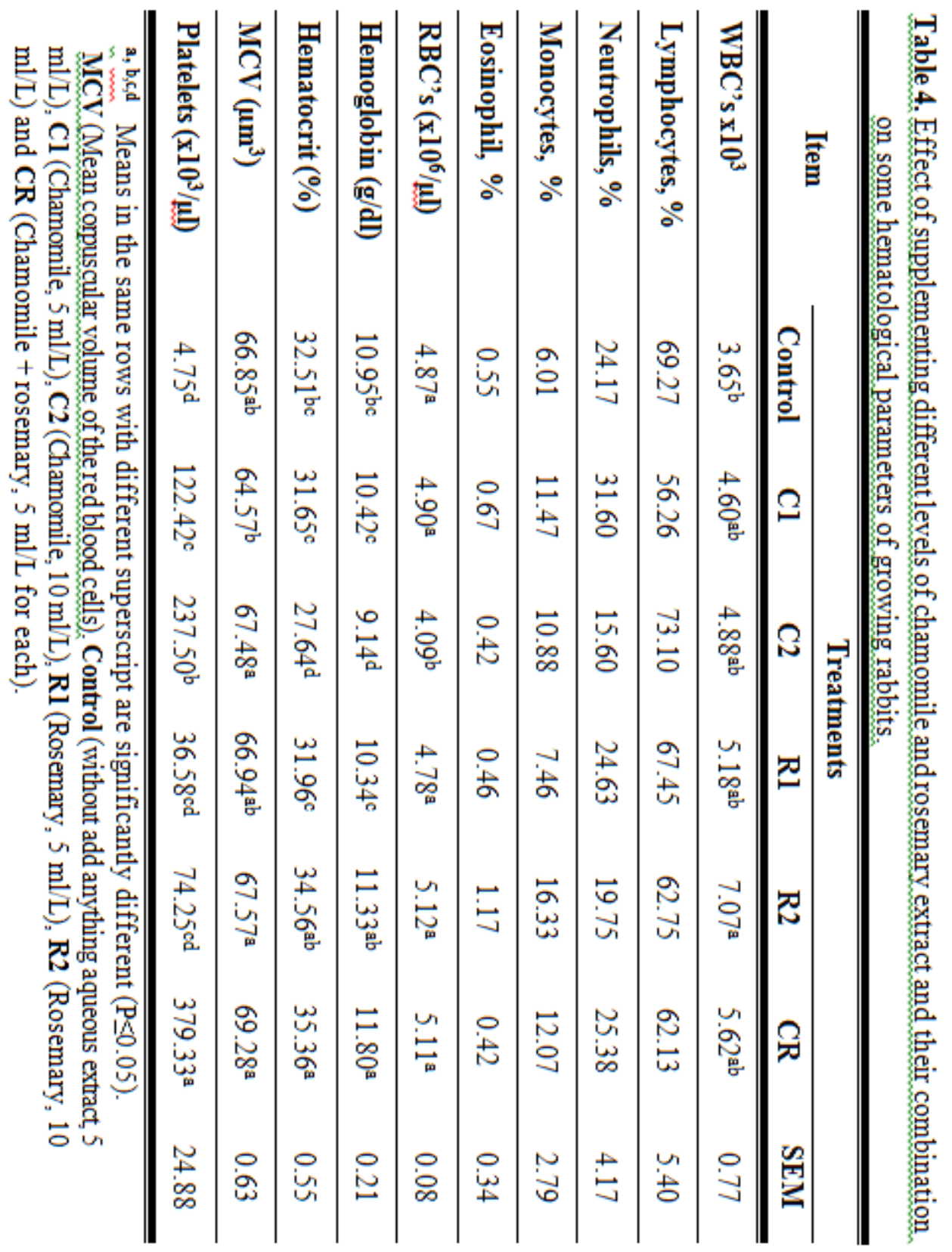


x103/mL), as reported by Moore et al. (2015) for rabbits. The results of our study were reflected with those reported by Attia et al. (2017) who indicated to the lack effect of rosemary leaves on most of the WBCs characteristics and suggested that addition, rosemary leaves at rate 0.5 to $1 \%$ was safe to rabbit bucks.

Results presented in in Table (4) and show that the RBCs count was decreased $(\mathrm{P}<0.05)$ with supplement chamomile aqueous extract $(10 \mathrm{ml} / \mathrm{L})$ to drinking water as compared with control one (4.09 vs. $4.87 \times 10^{6} / \mu 1$, respectively). However, no significant differences in RBC's count were found among treatments groups. The supplement rosemary aqueous extract alone in R2 group or their combination with chamomile extract in the $\mathrm{CR}$ group to the drinking water of rabbits improved $(\mathrm{P}<0.05)$ hemoglobin $(\mathrm{HGB})$ and hematocrit (HCT) concentration in compassion to control group and other treated groups. The addition chamomile $(5 \mathrm{ml} / \mathrm{L})$ to growing rabbits significantly reduced $(\mathrm{P}<0.05) \mathrm{MCV}$ value when compared with those of $\mathrm{C} 2, \mathrm{R} 2$ and $\mathrm{CR}$ groups. No changes in concentrations of mean corpuscular hemoglobin concentration (MCHC) with supplemented chamomile and rosemary extract or a combination of them. Supplementing chamomile extract alone (C2) or mixed with rosemary aqueous extracts $(\mathrm{CR})$ to growing rabbits were markedly increased $(\mathrm{P}<0.05)$ the platelet count when compared to other groups (Table 6). These changes were within the values of physiological normal ranges and no significant changes can be interpreted as physiological abnormal values. The values of RBCs in healthy rabbits range between 4.9-7.8 x10\% $/ \mu 1$ (Brewer, 2006).

The lower values of hemoglobin (HGB) and hematocrit (HCT) with supplement high dose of chamomile aqueous extract may be due to occurring damage in the kidney without effect on the vitality and morbidity of rabbits in C2 group, this is confirmed by an increase in MCV level. On the other hand, the higher value of platelet count with high level of chamomile or mixed with rosemary aqueous extracts may be attributed to potentially active chemical constituents of chamomile include terpenoids and spiroethers, flavonoids and coumarins, which possess great currency in reduced inflammation and improved healing of all wounds tissues (Sharifi-Rad et al., 2018 and Daneshfard et al., 2020), and the process of reduced inflammation and heal wounds needed increase the platelets count to help stop bleeding and heal wounds (Nurden et al., 2008).

Conclusively, supplement all of chamomile aqueous extract ( 5 or $10 \mathrm{ml} / \mathrm{L}$ ) or combined with rosemary $(5 \mathrm{ml} / \mathrm{L})$ to drink water of growing rabbits under heat stress condition has a positive effect on blood parameters and improve growth performance. 


\section{REFERENCES}

Abaza I. M.; A. T. El-Din; A. E. Abd El-Hamid and Hanan F. EL- Gayar (2014). Effect of chamomile flowers as feed additive on some biological parame-ters for growing rabbits. 7th International Poultry ConferenceProceeding, Ain Sukhna, Red Sea, Egypt : 335-344.

Al-Jamal, A. R. and Alqadi, T. (2011). Effects of rosemary (Rosmarinus officinalis) on lipid profile of diabetic rats. Jordan J Biol Sci, 4(4): 199203.

Assan, N. (2018). Plant based feed additives (phytogenic) as a primary solution to an antibiotic free nutritional program and feeding strategy in rabbit production. Scientific Journal of Animal Science, 7(3): 493-503.

Attia, Y. A., Hamed, R. S., Bovera, F., Abd El, A. E. H. E., Al-Harthi, M. A., and Shahba, H. A. (2017). Semen quality, antioxidant status and reproductive performance of rabbits bucks fed milk thistle seeds and rosemary leaves. Animal Reproduction Science, 184: 178-186.

Avallone, R., Zanoli, P., Puia, G., Kleinschnitz, M., Schreier, P., and Baraldi, M. (2000). Pharmacological profile of apigenin, a flavonoid isolated from Matricaria chamomilla. Biochemical pharmacology, 59(11): 1387-1394.

Badawi, L.; Bakr, E.; Mousa, M. and Abdel Ghaffar, M. (2016). The Effect of Feeding Rosemary and Marjoram on Reproductive Performance of Rabbit Does Under Sinai Conditions. Journal of Animal, Poultry \& Fish Production, 5(1): 9-16.

Bakr, E. S. O., Badawi, L. A. M., Abdel Ghaffar A. M. and Mousa, M. R. (2017). Effects of rosemary and marjoram supplementation on growth performance, digestibility and economic efficiency of growing rabbits. Egyptian Journal of Rabbit Science, 27(2): 245-266.

Brewer, N. R. (2006). Biology of the rabbit. Journal of the American Association for Laboratory Animal Science, 45(1), 8-24.

Cemek, M., Kağa, S., Şimşek, N., Büyükokuroğlu, M. E., and Konuk, M. (2008). Antihyperglycemic and antioxidative potential of Matricaria chamomilla L. in streptozotocin-induced diabetic rats. Journal of natural Medicines, 62(3): 284-293.

Daneshfard, B., Shahriari, M., Heiran, A., Nimrouzi, M., \& Yarmohammadi, H. (2020). Effect of chamomile on chemotherapyinduced neutropenia in pediatric leukemia patients: A randomized tripleblind placebo-controlled clinical trial. Avicenna Journal Of Phytomedicine, 10(1): 58-66. 
Eddouks, M., Lemhadri, A., Zeggwagh, N. A., and Michel, J. B. (2005). Potent hypoglycaemic activity of the aqueous extract of Chamaemelum nobile in normal and streptozotocin-induced diabetic rats. Diabetes Research And Clinical Practice, 67(3): 189-195.

El-Wardany, I.; El-Badawi, A.Y.; Helal, F.I.S.; Ali, G.M. and Aboelazab, O.M. (2015). Growth performance and hematological changes of growing New Zealand White rabbits fed diets supplemented with some natural antioxidants under heat stress conditions. Egyptian J. Nutrition and Feeds, 18(2): 237-245.

Emam, M. A. (2012). Comparative evaluation of antidiabetic activity of Rosmarinus officinalis L. and Chamomile recutita in streptozotocin induced diabetic rats. Agric. Biol. JN Am, 3(6): 247-252.

Erdelyi, M., Matics, Z., Gerencsér, Z., Princz, Z., Szendro, Z., and Mézes, M. (2008). Study of the effect of rosemary (Rosmarinus officinalis L) and garlic (Allium sativum) essential oils on the performance of rabbits. In 9th World Rabbit Congress-June Verona, Italy,10-13.

Ewuola, E. O., O. A. Sokunbi, T. K. Imam and C. U. Amadi (2011). Influence of dietary prebiotics and probiotics on blood profile of rabbits. Proc. 36th Ann. Conf. Nig. Soc. Anim. Produc.13-16 March, University of Abuja, Nigeria. pp $171-173$.

Fiume, M. M., Bergfeld, W. F., Belsito, D. V., Hill, R. A., Klaassen, C. D., Liebler, D. C., Marks Jr, J. G., Shank, R.C., Slaga, T. J., Snyder, P.W. and Heldreth, B. (2018). Safety Assessment of Rosmarinus officinalis (Rosemary)-Derived Ingredients as Used in Cosmetics. International Journal of Toxicology, 37(3): 12-50.

Gabr, M. N. (2016). Effects of the aqueous extract of Rosemarinus Officinalis $L$. (rosemary) leaves on lipid profile of diabetic adult male albino rats. $A l$ Azhar Medical Journal, 45(1): 185-194.

Gupta, A. K., and Misra, N. (2006). Hepatoprotective activity of aqueous ethanolic extract of Chamomile capitula in paracetamol intoxicated albino rats. Am J Pharmacol Toxicol, 1(1): 17-20.

Hamden, K., Carreau, S., Boujbiha, M. A., Lajmi, S., Aloulou, D., Kchaou, D., and Elfeki, A. (2008). Hyperglycaemia, stress oxidant, liver dysfunction and histological changes in diabetic male rat pancreas and liver: Protective effect of 17ß-estradiol. Steroids, 73(5): 495-501.

Harach, T., Aprikian, O., Monnard, I., Moulin, J., Membrez, M., Béolor, J. C., Raab, T., Macé, K. and Darimont, C. (2010). Rosemary (Rosmarinus officinalis L.) leaf extract limits weight gain and liver steatosis in mice fed a high-fat diet. Planta Medica, 76(06): 566-571. 
Helal, F., El-Badawi, A., El-Wardany, I., Ali, N., and Aboelazab, O. (2017). Effect of dietary moringa (Moringa oleifera) and rosemary (Rosmarinus officinalis L) leaves or their mixture on productive performance, carcass characteristics and antioxidant enzymes of rabbits reared under heat stress conditions. Agricultural Engineering International: CIGR Journal, 19(5): 184-192.

Iweala, E. E., and Oludare, F. D. (2011). Hypoglycemic effect, biochemical and histological changes of Spondias mombin Linn. and Parinari polyandra Benth. seeds ethanolic extracts in alloxan-induced diabetic rats. Journal of Pharmacology and Toxicology, 6(2): 101-112.

Kaseb, F., Yazdanpanah, Z., Biregani, A. N., Yazdi, N. B., and Yazdanpanah, Z. (2018). The effect of chamomile (Matricaria recutita L.) infusion on blood glucose, lipid profile and kidney function in Type 2 diabetic patients: a randomized clinical trial. Progress in Food \& Nutrition Science, 20: 110-118.

Matić, I. Z., Juranić, Z., Šavikin, K., Zdunić, G., Nađvinski, N., and Gođevac, D. (2013). Chamomile and marigold tea: Chemical characterization and evaluation of anticancer activity. Phytotherapy Research, 27(6):: 852-858.

Melillo A. (2007). Rabbit Clinical Pathology. Journal of exotic pet medicine, 16(3): 135-145.

Mizzi, L., Chatzitzika, C., Gatt, R., and Valdramidis, V. (2020). HPLC analysis of phenolic compounds and flavonoids with overlapping peaks. Food Technology and Biotechnology, 58(1): 12-19.

Moore, D. M., Zimmerman, K., and Smith, S. A. (2015). Hematological assessment in pet rabbits: Blood sample collection and blood cell identification. Veterinary Clinics: Exotic Animal Practice, 18(1): 9-19.

Nargesi, S., Moayeri, A., Ghorbani, A., Seifinejad, Y., Shirzadpour, E., \& Amraei, M. (2018). The effects of Matricaria chamomilla L. hydroalcoholic extract on atherosclerotic plaques, antioxidant activity, lipid profile and inflammatory indicators in rats. Biomedical Research and Therapy, 5(10): 2752-2761.

Ninomiya, K., Matsuda, H., Shimoda, H., Nishida, N., Kasajima, N., Yoshino, T., Morikawa, T. and Yoshikawa, M. (2004). Carnosic acid, a new class of lipid absorption inhibitor from sage. Bioorganic \& Medicinal Chemistry Letters, 14(8): 1943-1946.

Nurden, A. T., Nurden, P., Sanchez, M., Andia, I., and Anitua, E. (2008). Platelets and wound healing. Frontiers In Bioscience : A Journal And Virtual Library, 13: 3532-3548. 
Omer, H. A.; El-Nomeary, Y. A.; El-Kady, R. I.; Badr, A. M.; Ali, F. A.; Ahmed, S. M.; EL-Allawy, H. M. and Ibrahim, S. A. (2013). Improving the utilization of rabbit diets containing vegetable oil by using fennel (Foeniculum vulgare) and oregano (Origanum vulgare L.) as feed additives. Life Science Journal, 10(1): 2625-2636.

Osman, A., Imbabi, T. A., El-Hadary, A., Sabeq, I. I., Edris, S. N., Merwad, A. R. Azab, E.; Gobouri, A.A.; Mohammadein, A. and Sitohy, M. (2021). Health Aspects, Growth Performance, and Meat Quality of Rabbits Receiving Diets Supplemented with Lettuce Fertilized with Whey Protein Hydrolysate Substituting Nitrate. Biomolecules, 11(6): 835.

Rafraf, M., Zemestani, M., and Asghari-Jafarabadi, M. (2015). Effectiveness of chamomile tea on glycemic control and serum lipid profile in patients with type 2 diabetes. Journal of Endocrinological Investigation, 38(2): 163170.

Rassolov S. N. and Voroshilin R. A. (2018). Use of Camomile Extract when Growing Young Rabbits. Dostizheniya nauki i tekhniki APK, 32 (12): 5758.

Sampaio, T. L., da Costa, M. F. B., Meneses, G. C., Arrieta, M. C. V., Chaves Filho, A. J. M., de Morais, G. B. and Martins, A. M. C. (2016). Nephroprotective effects of (-)- $\alpha$-bisabolol against ischemic-reperfusion acute kidney injury. Phytomedicine, 23(14): 1843-1852.

SAS., (2001). Sas/ Stat Guide For Personal Computer (Version 8.2. end). SAS. INST., Cary, N.C.

Sharifi-Rad, M., Nazaruk, J., Polito, L., Morais-Braga, M. F. B., Rocha, J. E., Coutinho, H. D. M., and Sharifi-Rad, J. (2018). Matricaria genus as a source of antimicrobial agents: From farm to pharmacy and food applications. Microbiological Research, 215: 76-88.

Shati, A. A., and El-kott, A. F. (2014). Phytoprotective and Antioxidant Effects of German Chamomile Extract against Dimpylate-Induced HepatoNephrotoxicity in Rats. Advances in Life Science and Technology, 19: 3341.

Sotiropoulou, N. S., Megremi, S. F., and Tarantilis, P. (2020). Evaluation of antioxidant activity, toxicity, and phenolic profile of aqueous extracts of chamomile (Matricaria chamomilla L.) and sage (Salvia officinalis L.) prepared at different temperatures. Applied Sciences, 10 (7): 2270.

Steel, R. G., and Torrie, J. H. (1980). "Principles and Procedures of Statistics" A Biometrical Approach (2 nd Ed) Mc Grow- Hill Book Co., New York. 
Tucker, C. B., Rogers, A. R., and Schütz, K. E. (2008). Effect of solar radiation on dairy cattle behaviour, use of shade and body temperature in a pasture-based system. Applied Animal Behaviour Science, 109(2-4): 141154.

Zeghad, N. and Merghem, R. (2016). Antioxidant activity of flavonoids isolated from Rosmarinus officinalis L. Journal of Plant Science Research, 3(1): 142-149.

Zhang, Q. W., Lin, L. G., and Ye, W. C. (2018). Techniques for extraction and isolation of natural products: A comprehensive review. Chinese medicine, 13(1): 1-26.

\section{التأثيرات الاتتاجيه والفسيولوجيه للمستخلص المائي للبابونج وإكليل الجبل في الأرانب النيوزيلندى الناميةً

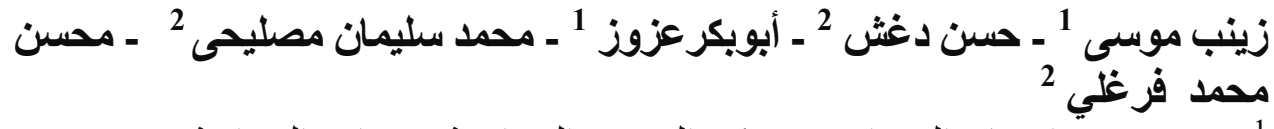

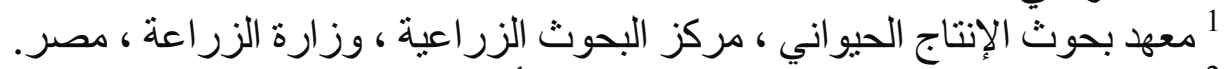

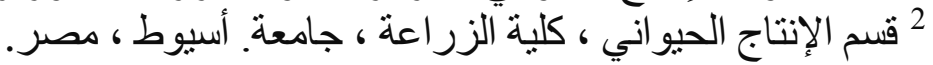 البريد الإلكتروني: zeinabmousa@yahoo.com}

أجريت هذه الدراسة لتقييم تأثير بعض المستخلصات العثبية على أداء النمو و

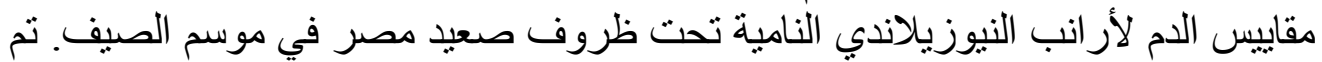

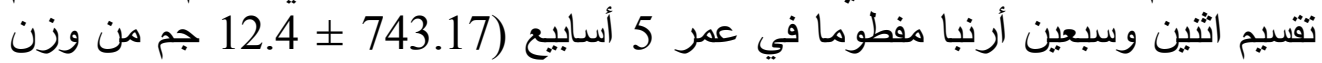

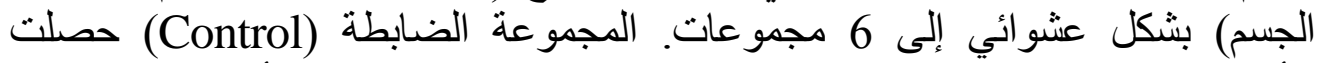

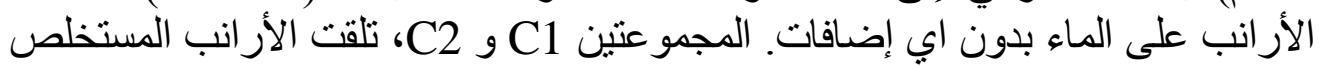

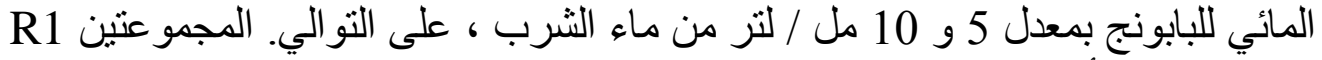

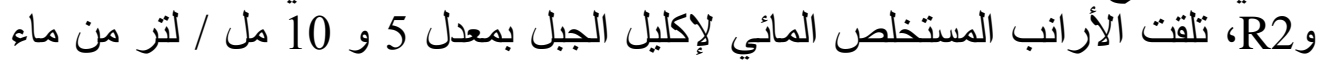

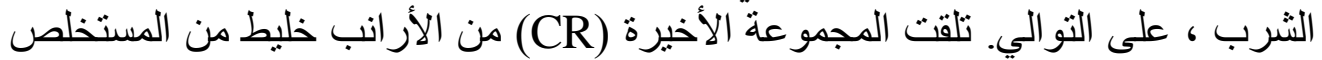

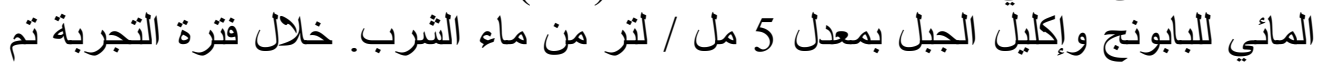
تسجيل وزن الجسم ومتوسط الزيادة اليومي في وزن الجسم و إستهلاك العلف (FI) و معدل

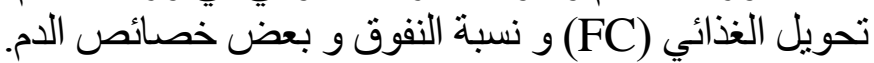

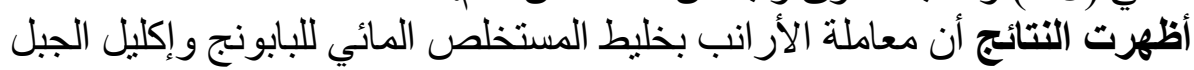
(CR) بمجموعات C1 و R1 و R2. لم يكن هنالك اي تغبير في إستهلاك العلف بين المجموعات 
P ) المعالجة و والمجموعة الضابطة. ومع ذللك، تحسن معدل التحويل الغذائي معنويا

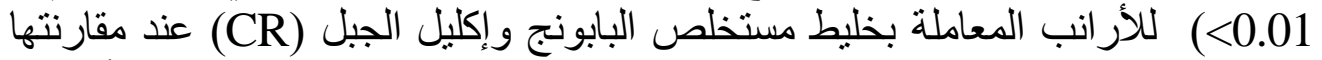

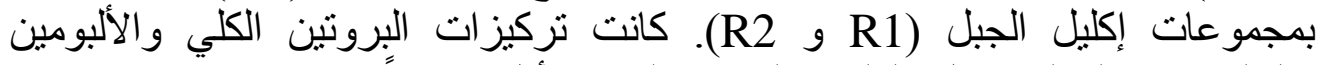

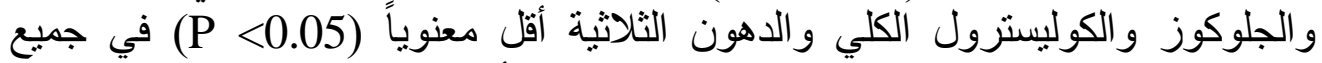

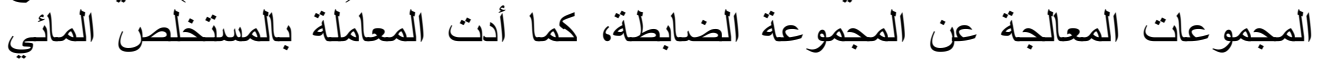

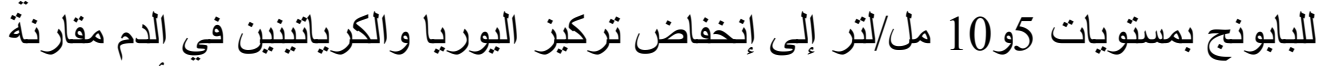

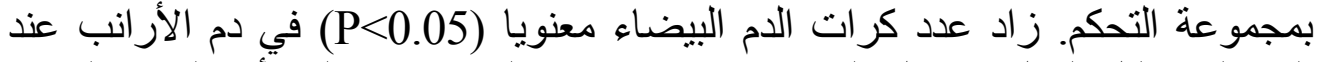

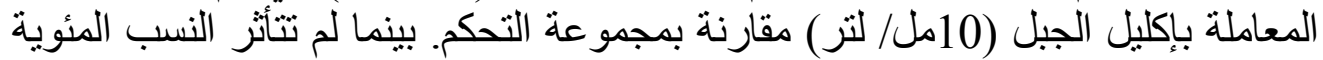

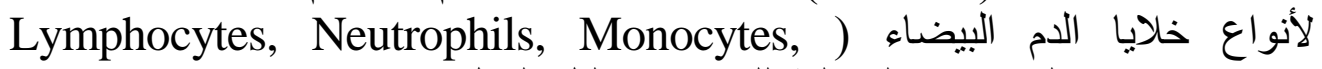
(Eosinophil

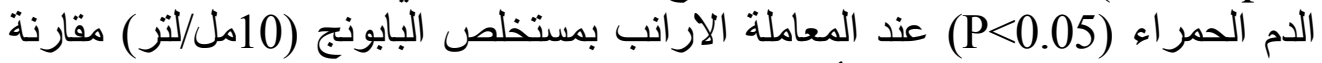
بمجمو عة التحكم (Control).

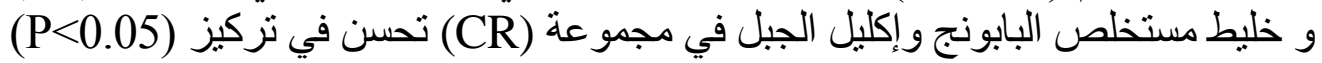

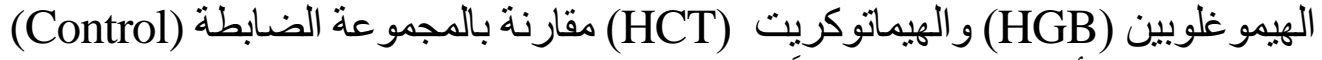

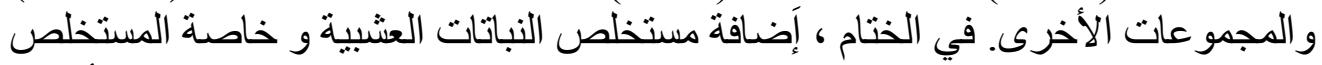

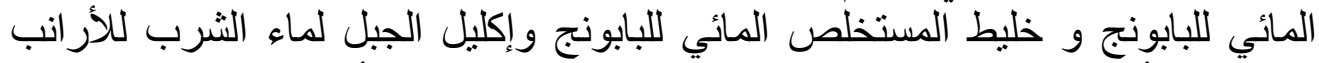

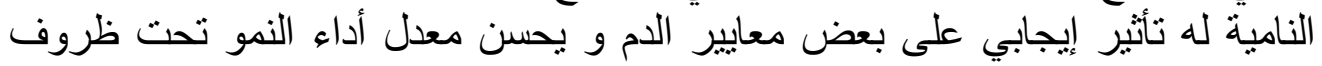

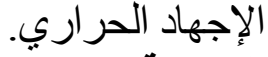
التوصية: نوصي بإستخدام المستخلص المائي لخليط البابونج والروزمارئ فاري (CR) في

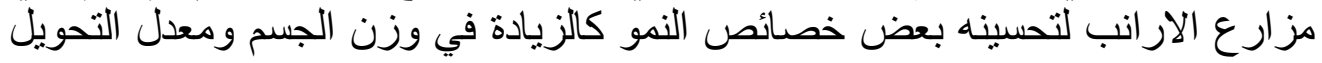

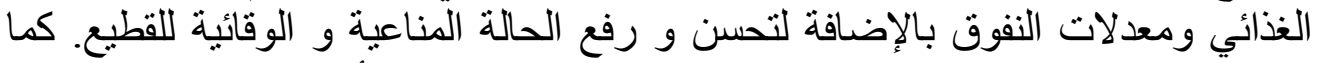

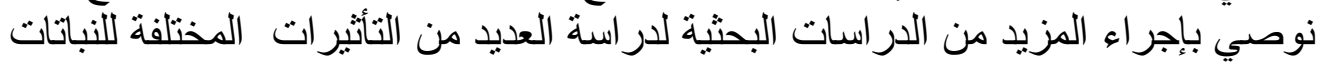

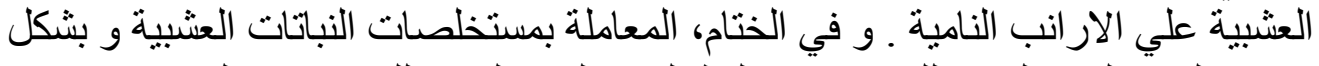

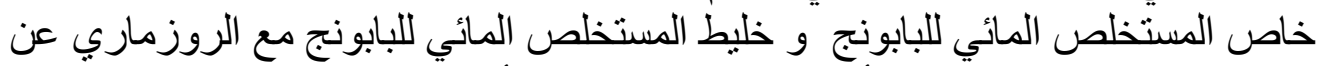

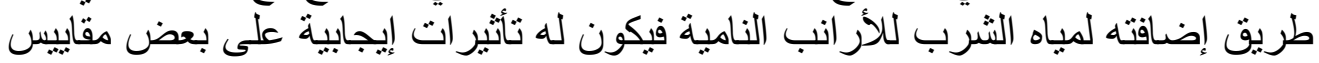
الدم و يحسن أداء النمو تحت ظروف الإجهاد الحراري. 